\title{
Association Between Cytomegalovirus Infection and Bad Obstetric Outcomes in Women from Kirkuk
}

\author{
Hala Mohamed Majeed Hassan ${ }^{1}$, Abdulghani Mohamed Alsamarai ${ }^{2}$, Zainab Khalil Mohamed \\ Aljumaili $^{3}$, Amina Hamed Alobaidi ${ }^{4}$ \\ ${ }^{1}$ Department of Microbiology, Tikrit University College of Science, Tikrit, Iraq \\ ${ }^{1}$ College of Veterinary Medicine \\ ${ }^{2}$ Departments of Medicine and Microbiology, Tikrit University College of Medicine, Tikrit, Iraq \\ ${ }^{2}$ Asthma, Allergy Centre, Tikrit Teaching Hospital, Tikrit, Iraq \\ ${ }^{3}$ Kirkuk Health Authority \\ ${ }^{4}$ Department of Biochemistry, Tikrit University College of Medicine, Tikrit, Iraq
}

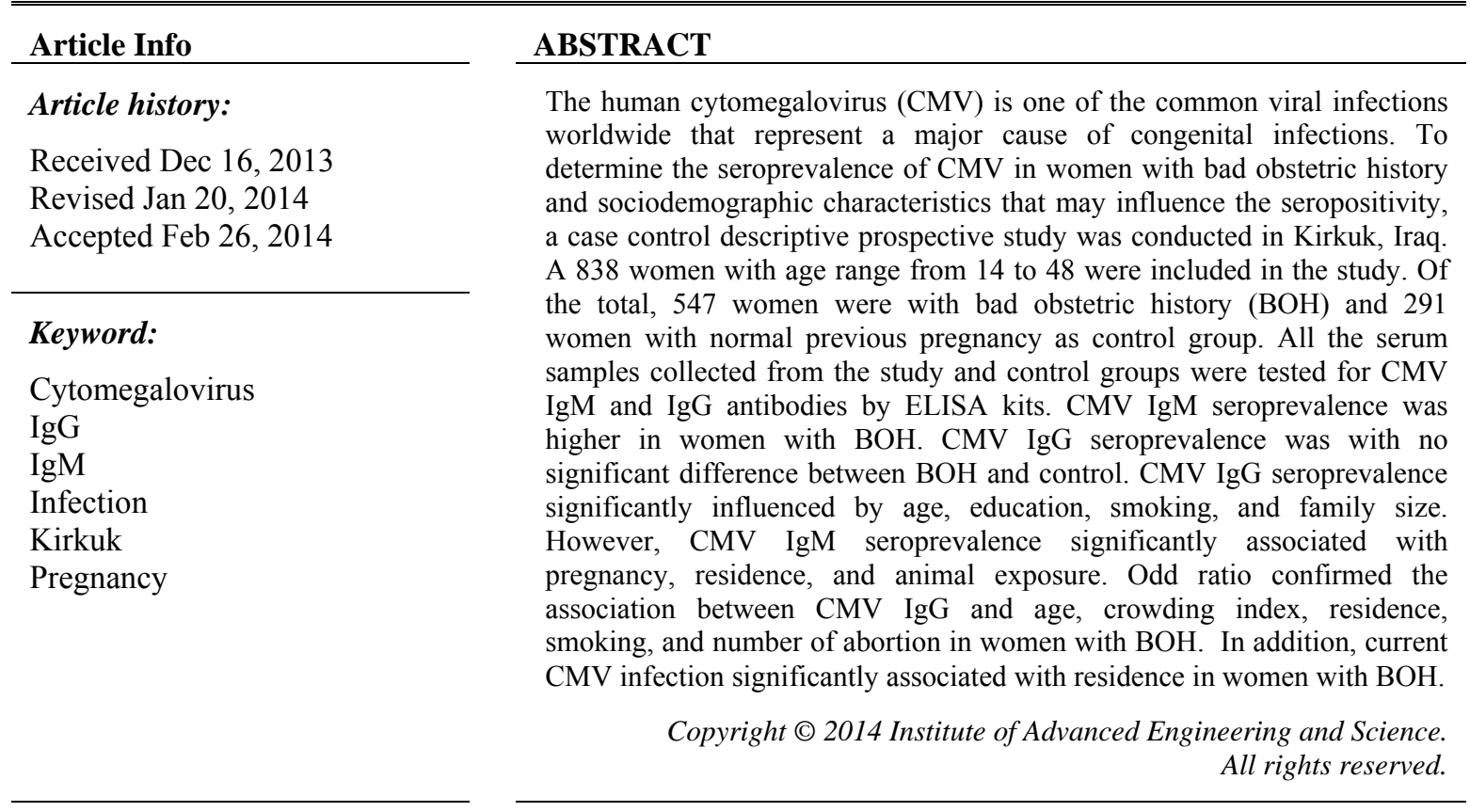

\section{Corresponding Author:}

Abdulghani Alsamarai,

Departments of Medicine and Microbiology,

Tikrit University College of Medicine,

Tikrit, Iraq.

Email: galsamarrai@yahoo.com.

\section{INTRODUCTION}

The human cytomegalovirus (HCMV) is the most common congenital viral infection worldwide and may be asymptomatic forms ( $90 \%$ of cases) to severe fetal damage and, in rare cases, death due to abortion [1]. Cytomegalovirus (CMV) infection during pregnancy is far more complex than other infections, due to the ability of the virus to be frequently reactivated during the child bearing age and be transmitted to the fetus inspite of maternal immunity [2]. HCMV infection was a complex phenomenon since the virus act as an immune modulator through elaborating an array of immune evasion strategies to avoid elimination from the host, and its viral proteins an involved in the regulation of cellular gene expression and induction of proinflammatory cytokine [3] or induction of autoimmune status [4].

There are many confounding studies about the association between CMV infection and pregnancy loss; the studies showed that HCMV can result in abortion or stillbirth [5],[6]. Cytomegalovirus is frequently 
causative agent of prenatal and perinatal infection and may lead to important complications on pregnancy [7]. The seropositivity of CMV varies widely around the world [8]. A review [9] of 40 globally reported studies on CMV seroepidemiology indicated a range of seropositivity from 30.4\% for Ireland [10] to $98.9 \%$ for Turkey [11] in pregnant/ and or child bearing age women. In addition, seroprevalence rate range was from $14.2 \%$ for Iran [12] to $91.05 \%$ for India [13] in women with bad obstetric history.

In Arab countries, we review 21 reported studies [9], which indicated a seroprevalence rate range from 77.8\% for Babylon, Iraq [14] to $88 \%$ for Jordan [15] in pregnant women. While the range of seroprevalence was from $4.8 \%$ for Baghdad, Iraq [16] to $95 \%$ for Jordan [15] in women with bad obstetric history.

In Iraq, the CMV seroepidemiology ranged from $8.02 \%$ (un acceptable low rate) to $90.4 \%$, a wide range of seroprevalence. In addition, the sample size of study population was from 60-230, thus this study conducted on a large size study population to clarify the seroepidemiology of CMV in women with BOH [9]. The aim of the present study is to determine the seroprevalence of CMV in women with bad obstetric history and sociodemographic characteristics that may influence the seropositivity.

\section{PATIENTS AND METHODS}

\section{Study Design and Settings:}

The study design is a Descriptive Case Control Study and was performed in Kirkuk General Hospital. The study proposal was approved by Tikrit University College of Science ethical committee and Kirkuk Health Authority Research Committee. Informed consent taken from each women included in the study.

\section{Study Population:}

The study population is women with childbearing age. Study population was recruited from Kirkuk General Hospital. A 838 women with age range from 14 to 48 were included in the study. Of the total, 547 women were with bad obstetric history $(\mathrm{BOH})$ and 291 women with normal previous pregnancy as control group. The demographic information of these groups are shown in Table 1. For serological analysis, $5-10 \mathrm{~mL}$ of venous blood was collected in a sterile container with strict aseptic precautions from each study subject. The serum was separated and stored in numbered aliquots at $-20{ }^{\circ} \mathrm{C}$ till assayed. All the serum samples collected from the study and control groups were tested for CMV IgM and IgG antibodies by commerciallyavailable (ELISA) kits. The results read by a Microwell reader and compared in a parallel manner with controls; optical density read at $450 \mathrm{~nm}$ on an ELISA reader.

\section{Collection of data}

All recruited women were subject for clinical examination and laboratory investigations were carried out for the study subjects to exclude other causes of foetal wastage, such as hypertension, diabetes mellitus, syphilis, Rh (rhesus) incompatibility, physical causes of abortion, and consanguinity. Subjects with known causes of foetal wastage were excluded from the study. All of them were interviewed to ascertain age, medical and obstetric information.

\section{Determination of CMV IgM and IgG:}

ELISA was used for determination of IgM and IgG for CMV and the test was performed according to manufacturer instructions. The kit purchased from BioCheck, Inc, 323 Vintage Park Dr, Foster City, CA 94404.

\section{Statistical Analysis:}

The proportion and the mean value were computed in appropriate situations. To find out any association between categorical data, Chi square test was employed using the SPSS (Version 16). If the sample size in $\mathrm{BOH}$ group not reach the targeted number Power Analysis were performed to determine the accuracy of findings. The study finding data were presented as frequency \pm SD and 95\% Confidence Interval. The determinants for HSV 2 infection is determined by calculation of Odd Ratio. Chi square used to determine the significance of differences between the groups.

\section{RESULTS AND DISCUSSION}

The overall CMV seroprevalence in our study population was $92.1 \%$ and an it was with no significant difference between women with $\mathrm{BOH}(91.2 \%)$ and women with normal pregnancy $(93.8 \%)$ 
outcomes $\left(\mathrm{X}^{2}=1.7, \mathrm{P}>0.05\right)$. Furthermore, current $\mathrm{CMV}$ infection was lower in women with $\mathrm{BOH}(3.8 \%)$ than that in women with normal pregnancy $(4.5 \%)$ outcomes $\left(X^{2}=0.19, P>0.05\right)$, Table 2 . There were a significant differences in $\mathrm{CMV}$ IgG seroprevalence between pregnant and non pregnant women in $\mathrm{BOH}$ $\left(\mathrm{X}^{2}=6.82, \mathrm{P}=0.007\right)$ and control $\left(\mathrm{X}^{2}=6.76, \mathrm{P}=0.008\right)$ groups. However, such pattern was demonstrated in control group for CMV $\operatorname{IgM}\left(\mathrm{X}^{2}=14.64, \mathrm{P}=0.000\right)$ seroprevalence, Table 2.

There was a non significant difference $\left(\mathrm{X}^{2}=0.6, \mathrm{P}>0.05\right)$ in $\mathrm{CMV}$ IgG seroprevalence between pregnant $(92.8 \%)$ and non- pregnant $(91.4 \%)$ women. In addition, current infection as demonstrated in IgM positivity was significantly higher $\left(\mathrm{X}^{2}=6.85, \mathrm{P}=0.007\right)$ in pregnant women $(5.8 \%)$ as compared to nonpregnant $(2.2 \%)$ women. Table 3.

Age significant seroprevalence variation was demonstrated for $\mathrm{CMV} \operatorname{IgG}$ in both $\mathrm{BOH}\left(\mathrm{X}^{2}=9.21\right.$, $\mathrm{P}=0.027)$ and control $\left(\mathrm{X}^{2}=20.5, \mathrm{P}=0.000\right)$. In $\mathrm{BOH}$ group, $\mathrm{CMV} \operatorname{IgG}$ seropositivity was $95.6 \%$ in women with age of $<20$ years, then declined in women with age. While in control group seropositivity was $100 \%$ in women with age of $<20$ and then decline in women with age of 20-29 years, but subsequently increased to reach $100 \%$ in women with age of $40-48$ years. CMV IgM seroprevalence was lowest in women with 30-39 years age $(3.3 \%)$, and highest $(4.6 \%)$ in women with age of $14-29$ years. However, in control CMV IgM was detected in women with $20-29$ years of age $(10.3 \%)$. In addition, there was a significant $(\mathrm{P}=0.03)$ higher CMV IgM seroprevalence (10.3\%) in control as compared to women with BOH (4.6\%) in the age of 20 to 29 years. While in the age group $30-39$ years, CMV IgM was significantly higher $(\mathrm{P}=0.007)$ in women with $\mathrm{BOH}(3.3 \%)$ as that in control $(0 \%)$, Table 4.

CMV IgG seroprevalence was with significant differences between control and women with $\mathrm{BOH}$. The seroprevalence rate was significantly $(\mathrm{P}=0.007)$ lower in control $(86.6 \%)$ as compared to women with $\mathrm{BOH}(94.6 \%)$ with age of 20-29 years, while with reverse pattern for the age groups of 30-39 (control ,98.9\%; BOH, 87.4\%, p=0.002) and 40-48 years (control ,100\%; BOH, 87.4\%, $\mathrm{p}=0.038$ ). Table 4.

The CMV IgM seroprevalence was higher in women with age of $<30$ years $(4.2 \%)$ as compared to those $>30$ years $(3.4 \%)$, but the difference not reach a significant level $\left(\mathrm{X}^{2}=0.22, \mathrm{P}=>0.05\right)$. While in the control group the rate also higher in women $<30$ years $(7.5 \%)$ as compared to those $>30$ years $\left(0 \%, X^{2}=9.28\right.$, $\mathrm{P}=0.002$ ), Table 5. OR also not confirmed a significant association between age of $<30$ years and CMV IgM $(\mathrm{OR}=0.81, \mathrm{P}>0.05)$, Table 6 . The $\mathrm{CMV}$ IgG seroprevalence was significantly $\left(\mathrm{X}^{2}=9.17, \mathrm{P}=0.003\right)$ higher in $\mathrm{BOH}$ women of $<30$ years $(94.7 \%)$ than those of $>30$ years $(87.4 \%)$. While in the control group, it was significantly higher $\left(\mathrm{X}^{2}=9.75, \mathrm{P}=0.002\right)$ in women with age $>30$ years $(99.2 \%)$, Table 5 . OR confirmed the association between age of $<30$ years and CMV $\operatorname{IgG}(\mathrm{OR}=2.594, \mathrm{P}=0.003)$ seropositivity, while CMV $\operatorname{IgM}$ seropositivity was associated with age of $<30$ years $(\mathrm{OR}=2.38, \mathrm{P}=0.028)$ when data of $\mathrm{BOH}$ and control collected together. In women with age of $>30$ years, there were a significant differences between $\mathrm{BOH}$ and control group in CMV IgM seroprevalence $\left(\mathrm{X}^{2}=4.15, \mathrm{P}=0.042\right)$ and CMV IgG seroprevalence $\left(\mathrm{X}^{2}=13.8\right.$, $\mathrm{P}=0.000)$, Tables $5 \& 6$.

Women living in rural areas demonstrate $92 \%$ seropositivity for CMV IgG, while in urban area the seropositivity was $90.9 \%$, with no significant difference $\left(\mathrm{X}^{2}=0.169, \mathrm{P}>0.05\right)$. However, current infection was significantly $\left(\mathrm{X}^{2}=10.18, \mathrm{P}=0.000\right)$ higher in women from urban $(5.6 \%)$ areas as it was not detected in women from rural $(0 \%)$ areas, Table 7 . OR confirmed the association between residence and CMV seroprevalence for $\operatorname{IgM}(\mathrm{OR}=29.71, \mathrm{P}=0.01)$, but not for $\operatorname{IgG}(\mathrm{OR}=1.146, \mathrm{P}>0.05)$, Table 8 .

CMV IgG seropositivity was about the same $\left(\mathrm{X}^{2}=0.001, \mathrm{P}>0.05\right)$ in working women $(91.1 \%)$ as compared to housewife (91.2\%) women. However, CMV IgM (current infection) was $4.2 \%$ in housewife and not detected in any working women $(0 \%)$. OR not confirm any significant association between occupation and both $\operatorname{IgM}(\mathrm{OR}=0.246, \mathrm{P}>0.05)$ and $\operatorname{IgG}(\mathrm{OR}=0.985, \mathrm{P}>0.05)$, Tables $7 \& 8$.

Education levels significantly influenced CMV seroprevalence for $\operatorname{IgG}\left(\mathrm{X}^{2}=4.33, \mathrm{P}=0.037\right)$ in our study population, but not $\operatorname{IgM}\left(\mathrm{X}^{2}=0.03, \mathrm{P}>0.05\right)$. OR confirmed such association for $\operatorname{IgG}(\mathrm{OR}=2.003$, $=0.026)$, but not for $\operatorname{IgM}(\mathrm{OR}=0.503, \mathrm{P}>0.05)$, Tables $7 \& 8$. Small size (crowding index $<3)$ families were with higher seroprevalence for CMV IgM $(4.2 \%)$, but not reach significant $\left(\mathrm{X}^{2}=0.16, \mathrm{P}>0.05\right)$. However, CMV IgG was significantly $\left(\mathrm{X}^{2}=73.4, \mathrm{P}=0.000\right)$ lower $(75.2 \%)$ in families of $>3$ crowding index. OR confirmed significant association between family size and $\mathrm{IgG}$ seropositivity $(\mathrm{OR}=17.713, \mathrm{P}=0.0001)$, but not for $\operatorname{IgM}\left(\mathrm{X}^{2}=0.711, \mathrm{P}>0.05\right)$, Tables $7 \& 8$.

CMV IgM seropositivity rate was about the same in smoker (4\%) and non- smoker $(3.6 \%)$ women with $\mathrm{BOH}\left(\mathrm{X}^{2}=0.04, \mathrm{P}>0.05\right)$. However, $\mathrm{CMV} \operatorname{IgG}$ seropositivity was significantly $\left(\mathrm{X}^{2}=8.93, \mathrm{P}=0.003\right)$ higher $(94.2 \%)$ in smoker than non-smoker $(86.8 \%)$ women, Table 7. OR confirmed the association between smoking and CMV IgG seropositivity $\left(\mathrm{X}^{2}=2.461, \mathrm{P}=0.002\right)$, but not for current infection $\left(\mathrm{X}^{2}=0.912, \mathrm{P}>0.05\right)$, Table 8 .

CMV IgG seroprevalence was higher in BOH women with haemoglobin of $<11 \mathrm{~g} / \mathrm{dl}(92.1 \%)$ than those with $>11 \mathrm{~g} / \mathrm{dl}(90.9 \%)$, but the difference was not significant $\left(\mathrm{X}^{2}=0.06, \mathrm{P}>0.05\right)$. OR not confirmed an association between haemoglobin level in women with $\mathrm{BOH}$ and both $\mathrm{CMV} \operatorname{IgM}(\mathrm{OR}=0.813, \mathrm{P}>0.05)$ and

Association Between Cytomegalovirus Infection and Bad Obstetric Outcomes in Women (Hala Mohamed) 
$\operatorname{IgG}(\mathrm{OR}=0.863, \mathrm{P}>0.05)$. $\mathrm{BOH}$ women exposed to animal was with higher $(92.8 \%)$ non significant $\left(\mathrm{X}^{2}=0.91\right.$, $\mathrm{P}>0.05)$ CMV IgG seroprevalence than non exposed (90.4\%). However, CMV IgM was significantly $\left(\mathrm{X}^{2}=8.99, \mathrm{P}=0.001\right)$ higher $(5.7 \%)$ in non exposed $\mathrm{BOH}$ women $(0.5 \%)$. OR not confirmed association between animal exposure and both $\mathrm{CMV} \operatorname{IgG}(\mathrm{OR}=1.37, \mathrm{P}>0.05)$ and $\operatorname{IgM}(\mathrm{OR}=0.086, \mathrm{P}>0.05)$ in women with $\mathrm{BOH}$, Tables 7 \& 8 .

There was a significant $\left(\mathrm{X}^{2}=6.1, \mathrm{P}=0.01\right)$ differences in $\mathrm{CMV}$ IgG seroprevalence in women with repeated abortion of $>3(89.5 \%)$ and those below (97.4\%), while IgM not show a significant difference $\left(\mathrm{X}^{2}=0.63, \mathrm{P}>0.05\right)$. OR confirmed an association between number of abortion and CMV IgG seropositivity $(\mathrm{OR}=4.391, \mathrm{P}=0.01)$, Tables $7 \& 8$. Women with history of congenital anomalies were with higher $(95.9 \%$; $\left.\mathrm{X}^{2}=1.48, \mathrm{P}>0.05\right)$ CMV IgG seroprevalence than those without (90.8\%). In addition, CMV IgM seropositivity was $4.1 \%$ in women with history of congenital anomalies and $3.8 \%$ in those without $\left(\mathrm{X}^{2}=0.009, \mathrm{P}>0.05\right)$. OR not confirmed an association between congenital anomalies and $\mathrm{CMV}$ IgG $(\mathrm{OR}=0.418, \mathrm{P}>0.05)$ and $\mathrm{CMV} \operatorname{IgM}\left(\mathrm{X}^{2}=0.932, \mathrm{P}>0.05\right)$, Tables $7 \& 8$.

Table 1. Study population

\begin{tabular}{|c|c|c|c|}
\hline \multicolumn{2}{|c|}{ Group } & \multirow{2}{*}{$\begin{array}{c}\text { Number } \\
292\end{array}$} & \multirow{2}{*}{$\frac{\text { Mean age } \pm \text { SD in years }}{28.35 \pm 7.25}$} \\
\hline Women with bad & Pregnant & & \\
\hline obstetric history & Non pregnant & 255 & $28.24 \pm 6.81$ \\
\hline & Total & 547 & \\
\hline \multirow{3}{*}{$\begin{array}{l}\text { Women with normal } \\
\text { pregnancy }\end{array}$} & Pregnant & 140 & $27.40 \pm 6.24$ \\
\hline & Non pregnant & 151 & $28.06 \pm 10.51$ \\
\hline & Total & 291 & \\
\hline \multirow{2}{*}{$\begin{array}{l}\text { Grand total } \\
\text { P value }\end{array}$} & & 838 & $28.42 \pm 7.72$ \\
\hline & & NS & \\
\hline
\end{tabular}

Table 2. Cytomegalovirus seroprevalence in women with bad obstetric history

\begin{tabular}{|c|c|c|c|}
\hline \multirow{2}{*}{\multicolumn{2}{|c|}{ Group [Number] }} & \multicolumn{2}{|c|}{ Number positive [Percent] } \\
\hline & & \multirow{2}{*}{$\frac{\text { IgM }}{12[4.1]}$} & \multirow{2}{*}{$\frac{\text { IgG }}{275[94.2]}$} \\
\hline Bad obstetric history & Pregnant & & \\
\hline & Non- pregnant [255] & $9[3.5]$ & $224[87.8]$ \\
\hline & $X^{2}$ & 0.124 & 6.82 \\
\hline & $\mathrm{P}$ value & NS & 0.007 \\
\hline & Total & $21[3.8]$ & 499 [91.2] \\
\hline \multirow[t]{5}{*}{ Normal pregnancy } & Pregnant & $13[9.3]$ & $126[90]$ \\
\hline & Non- pregnant $[151]$ & $0[0]$ & $147[97.4]$ \\
\hline & $\mathrm{X}^{2}$ & 14.64 & 6.76 \\
\hline & $P$ value & 0.000 & 0.008 \\
\hline & Total & $13[4.5]$ & $273[93.8]$ \\
\hline \multicolumn{2}{|l|}{ Grand total } & $34[4.1]$ & $772[92.1]$ \\
\hline \multicolumn{2}{|c|}{$\mathrm{X}^{2} \quad \mathrm{BOH}$ versus Normal Pregnancy } & 0.19 & 1.76 \\
\hline \multicolumn{2}{|c|}{$\mathrm{P}$ value $\mathrm{BOH}$ versus Normal Pregnancy } & NS & NS \\
\hline
\end{tabular}

Table 3. Cytomegalovirus seroprevalence in pregnant compared to non-pregnant women

\begin{tabular}{lccc}
\hline \multicolumn{2}{c}{ Group [Number] } & \multicolumn{2}{c}{ Number positive [Percent] } \\
\cline { 2 - 4 } & & IgM & IgG \\
\hline Pregnant & {$[432]$} & $25[5.8]$ & $401[92.8]$ \\
Non- pregnant & {$[406]$} & $9[2.2]$ & $371[91.4]$ \\
$X^{2}$ & & 6.85 & 0.60 \\
P value & & $\mathbf{0 . 0 0 7}$ & NS \\
\hline
\end{tabular}

Table 4 . Comparison of Frequency of Cytomegalovirus in BOH compared to control agents in

\begin{tabular}{|c|c|c|c|c|c|c|c|c|}
\hline \multirow[t]{2}{*}{$\begin{array}{c}\text { Age group in } \\
\text { years }\end{array}$} & \multicolumn{4}{|c|}{$\begin{array}{c}\operatorname{IgM} \\
\text { Number positiveltotal [\%] }\end{array}$} & \multicolumn{4}{|c|}{$\begin{array}{c}\text { IgG } \\
\text { Number positiveltotal [\%] }\end{array}$} \\
\hline & Control & Patient & $\mathrm{X}^{2}$ & $\mathrm{P}$ value & Control & Patient & $\mathrm{X}^{2}$ & P Value \\
\hline $14-19$ & $\begin{array}{c}0 \backslash 47 \\
{[0]}\end{array}$ & $\begin{array}{l}1 \backslash 45 \\
{[4.6]}\end{array}$ & 0.97 & NS & $\begin{array}{l}47 \backslash 47 \\
{[100]}\end{array}$ & $\begin{array}{l}43 \backslash 45 \\
{[95.6]}\end{array}$ & 2.14 & $\mathrm{NS}$ \\
\hline $20-29$ & $\begin{array}{l}13 \backslash 126 \\
{[10.3]}\end{array}$ & $\begin{array}{c}11 \backslash 240 \\
{[4.6]}\end{array}$ & 4.43 & 0.03 & $\begin{array}{c}109 \backslash 126 \\
{[86.6]}\end{array}$ & $\begin{array}{c}227 \backslash 240 \\
{[94.6]}\end{array}$ & 7.16 & 0.007 \\
\hline $30-39$ & $\begin{array}{c}0 \backslash 86 \\
{[0]}\end{array}$ & $\begin{array}{l}7 \backslash 214 \\
{[3.3]}\end{array}$ & 7.3 & 0.007 & $\begin{array}{l}85 \backslash 86 \\
{[98.9]}\end{array}$ & $\begin{array}{c}187 \backslash 214 \\
{[87.4]}\end{array}$ & 9.51 & 0.002 \\
\hline $40-48$ & $\begin{array}{c}0 \backslash 32 \\
{[0]}\end{array}$ & $\begin{array}{l}2 \backslash 48 \\
{[4.2]}\end{array}$ & 1.37 & NS & $\begin{array}{l}32 \backslash 32 \\
{[100]}\end{array}$ & $\begin{array}{l}42 \backslash 48 \\
{[87.5]}\end{array}$ & 4.32 & 0.038 \\
\hline$X^{2}$ & 17.8 & 0.88 & & & 20.5 & 9.21 & & \\
\hline$P$ value & 0.000 & NS & & & 0.000 & 0.027 & & \\
\hline
\end{tabular}


Table 5 . Frequency of CMV according to age of $<30$ and above

\begin{tabular}{|c|c|c|c|c|c|c|c|c|c|c|c|}
\hline \multirow[t]{2}{*}{ Variable } & \multirow{2}{*}{$\begin{array}{l}\text { Age } \\
\text { in } \\
\text { years. }\end{array}$} & \multicolumn{2}{|c|}{ Total No. } & \multicolumn{4}{|c|}{$\begin{array}{c}\text { IgM } \\
\text { Number positive } \\
{[\%]}\end{array}$} & \multicolumn{4}{|c|}{$\begin{array}{c}\text { IgG } \\
\text { Number positive } \\
{[\%]} \\
\end{array}$} \\
\hline & & Con. & Pat & Con. & Pat. & $X^{2}$ & $\mathrm{P}$ & Con. & Pat. & $\mathrm{X}^{2}$ & $\mathrm{P}$ \\
\hline CMV & $14-29$ & 173 & 285 & $\begin{array}{c}13 \\
{[7.5]}\end{array}$ & $12[4.2]$ & 2.28 & $\mathrm{NS}$ & $156[90.2]$ & $270[94.7]$ & 3.45 & NS \\
\hline & $30-48$ & 118 & 262 & $\begin{array}{c}0 \\
{[0]}\end{array}$ & 9 [3.4] & 4.15 & 0.042 & 117 [99.2] & 229 [87.4] & 13.8 & 0.000 \\
\hline & $X^{2}$ & & & & 0.22 & & & 9.75 & 9.17 & & \\
\hline & $\mathrm{P}$ & & & & NS & & & 0.002 & 0.003 & & \\
\hline
\end{tabular}

Table 6 Odd ratio of Cytomegalovirus in regards to age of women lower than 30 years

\begin{tabular}{lll}
\hline Variable & Odd ratio [95\% Confidence interval] & P value \\
\hline CMV IgM & $0.810[0.335-1.953]$ & NS \\
CMV IgG & $2.594[1.374-4.896]$ & $\mathbf{0 . 0 0 3}$
\end{tabular}

Table 7 Frequency of HSV 2 IgG and IgM in regard to sociodemographic characteristics

\begin{tabular}{|c|c|c|c|}
\hline \multirow[b]{2}{*}{ Variable } & \multirow[b]{2}{*}{ [Number] } & \multicolumn{2}{|c|}{ Number positive [Percent] } \\
\hline & & $\operatorname{IgM}$ & $\mathrm{IgG}$ \\
\hline Residence & $\begin{array}{l}\text { Rural [174] } \\
\text { Urban [373] } \\
\mathrm{X}^{2} \\
\text { P value }\end{array}$ & $\begin{array}{c}0[0] \\
21[5.6] \\
10.187 \\
0.000\end{array}$ & $\begin{array}{c}160[92] \\
339[90.9] \\
0.169 \\
\text { NS }\end{array}$ \\
\hline Occupation & $\begin{array}{l}\text { House wife [502] } \\
\text { Working } \\
\mathrm{X}^{2} \\
\mathrm{P} \text { value }\end{array}$ & $\begin{array}{c}21[4.2] \\
0[0] \\
1.958 \\
\mathrm{NS}\end{array}$ & $\begin{array}{c}458[91.2] \\
41[91.1] \\
0.001 \\
\text { NS }\end{array}$ \\
\hline Education & $\begin{array}{l}\text { Uneducated [142] } \\
\text { Educated } \\
\mathrm{X}^{2} \\
\mathrm{P} \text { value }\end{array}$ & $\begin{array}{c}5[3.5] \\
15[3.7] \\
0.03 \\
\text { NS }\end{array}$ & $\begin{array}{c}123[86.6] \\
376[92.8] \\
4.33 \\
\mathbf{0 . 0 3 7}\end{array}$ \\
\hline Crowding Index & $\begin{array}{l}\leq \quad 3[382] \\
3.1-8[165] \\
\mathrm{X}^{2} \\
\mathrm{P} \text { value }\end{array}$ & $\begin{array}{c}16[4.2] \\
5[3] \\
0.16 \\
\mathrm{NS}\end{array}$ & $\begin{array}{c}375[98.2] \\
124[75.2] \\
73.4 \\
0.000\end{array}$ \\
\hline Smoking & $\begin{array}{l}\text { Present }[327] \\
\text { No smoking [220] } \\
\mathrm{X}^{2} \\
\mathrm{P} \text { value }\end{array}$ & $\begin{array}{c}13[4] \\
8[3.6] \\
0.04 \\
\text { NS }\end{array}$ & $\begin{array}{c}308[94.2] \\
191[86.8] \\
8.93 \\
0.003\end{array}$ \\
\hline Haemoglobin & $\begin{array}{ll}<11 & {[151]} \\
11-19 & {[396]} \\
X^{2} & \\
P \text { value } & \end{array}$ & $\begin{array}{c}5[3.3] \\
16[4] \\
0.04 \\
\text { NS }\end{array}$ & $\begin{array}{c}139[92.1] \\
360[90.9] \\
0.06 \\
\text { NS }\end{array}$ \\
\hline Animal exposure & $\begin{array}{ll}\text { Present } & {[194]} \\
\text { Absent } & {[353]} \\
\mathrm{X}^{2} & \\
\text { P value } & \end{array}$ & $\begin{array}{c}1[0.5] \\
20[5.7] \\
8.99 \\
0.001\end{array}$ & $\begin{array}{c}180[92.8] \\
319[90.4] \\
0.91 \\
\text { NS }\end{array}$ \\
\hline Abortion number & $\begin{array}{l}1-2[116] \\
3-8[431] \\
X^{2} \\
P \text { value }\end{array}$ & $\begin{array}{c}3[2.6] \\
18[4.2] \\
0.63 \\
\mathrm{NS}\end{array}$ & $\begin{array}{c}113[97.4] \\
386[89.5] \\
6.1 \\
0.01\end{array}$ \\
\hline Congenital anomalies & $\begin{array}{l}\text { Absent [498] } \\
\text { Present [49] } \\
X^{2} \\
\text { P value }\end{array}$ & $\begin{array}{c}19[3.8] \\
2[4.1] \\
0.009 \\
\text { NS }\end{array}$ & $\begin{array}{c}452[90.8] \\
47[95.9] \\
1.48 \\
\text { NS }\end{array}$ \\
\hline
\end{tabular}


Table 8. Association of CMV seropositivity with sociodemographic characteristics using Bivariate

\begin{tabular}{|c|c|c|c|}
\hline Variable & & Odd ratio [95\% Confidence interval] & $\mathrm{P}$ value \\
\hline \multirow{2}{*}{$\begin{array}{l}\text { Occupation } \\
\text { [Housewife versus Official] }\end{array}$} & IgM & $0.246[0.015-4.13]$ & NS \\
\hline & $\operatorname{IgG}$ & $0.985[0.337-2.87]$ & NS \\
\hline \multirow{2}{*}{$\begin{array}{l}\text { Crowding Index } \\
{[<3 \text { versus }>3]}\end{array}$} & $\operatorname{IgM}$ & $0.711[0.256-1.974]$ & NS \\
\hline & IgG & $17.713[7.748-40.495]$ & $<0.0001$ \\
\hline \multirow[t]{2}{*}{ Education [Educated versus Uneducated] } & $\operatorname{IgM}$ & $0.503[0.115-2.198]$ & NS \\
\hline & $\operatorname{IgG}$ & $2.003[1.085-3.698]$ & 0.026 \\
\hline Residence & $\operatorname{IgM}$ & $29.71[1.788-493.858]$ & 0.01 \\
\hline [Rural versus Urban] & IgG & $0.872[0.455-1.671]$ & NS \\
\hline \multirow[t]{2}{*}{ Smoking } & $\operatorname{IgM}$ & $0.912[0.371-2.237]$ & NS \\
\hline & $\operatorname{IgG}$ & $2.461[1.343-4.512]$ & 0.002 \\
\hline \multirow[t]{2}{*}{ Haemoglobin } & $\operatorname{IgM}$ & $0.813[0.293-2.261]$ & NS \\
\hline & IgG & $0.863[0.436-1.707]$ & NS \\
\hline \multirow[t]{2}{*}{ Animal exposure } & $\operatorname{IgM}$ & $0.086[0.012-0.648]$ & NS \\
\hline & IgG & $1.370[0.716-2.622]$ & NS \\
\hline \multirow[t]{2}{*}{ Abortion number } & $\operatorname{IgM}$ & $0.609[0.176-2.105]$ & NS \\
\hline & IgG & $4.391[1.339-14.396]$ & 0.01 \\
\hline \multirow[t]{2}{*}{ Congenital anomalies } & $\operatorname{IgM}$ & $0.932[0.211-4.126]$ & NS \\
\hline & IgG & $0.418[0.098-1.777]$ & NS \\
\hline
\end{tabular}

\section{Discussion}

The present study shows a high CMV IgG overall seroprevalence (92.1\%), with no significant differences between rate in women with $\mathrm{BOH}$ and that with normal pregnancy. Thus the susceptibility rate in our study population was $7.9 \%$, which was higher to that reported recently for Turkey [11],[17]-[22], Nigeria [23],[24], Brazil [25], Iran [26],[27], Bangladesh [28], Korea [29], and Cuba [30]. However, our study susceptibility was lower than that reported for France [31], Nepal [32], India [13],[33],[34], Switzerland [35], Croatia [36], Malaysia [37], Iran [12],[38], Poland [39], Ireland [10], Russia [40], Taiwan [41], Germany [42], Azerbaijan [43], Bangladesh [44], and Brazil [45]. In comparison to Arab countries, this study susceptibility rate was lower to that reported for Egypt [46], Sudan [47], Syria [48], and Jordan [15], but similar to that reported for Saudi Arabia [49], and higher to rate in Qatar [50], Sudan [51], and Tunisia [52].

The comparison with Iraqi studies, this study was with higher rate to that reported for Kirkuk [53], but was lower to that reported for Baghdad, Waset, Al-Anbar, Al-Hila, Thi Qar, Kirkuk, Diwaniya, and Babylon [54],[14],[15],[55]-[61]. However, the mostly deviated rates were that reported for Kirkuk [59], Baghdad [16] and Thi Qar [62], which they reported a very low seroprevalence rate of CMV.

In the present study and in that reported globally show a high seroprevalence of CMV $\operatorname{IgG}$ antibodies, however, this preconceptional immunity against CMV provide incomplete protection against intrauterine transmission, and adverse outcomes can occur in infected children born to women who were seropositive prior to pregnancy [63]-[67]. Transplacental transmission of CMV in women with preexisting seroimmunity may be a secondary to virus reactivation [68] or to infection with a new different CMV strain (reinfection) [69] during pregnancy.

Previous immunization with CMV is not perfectly protective against either reinfection or vertical transmission of infection from mother to fetus [20],[23]. In a recent study, approximately one third of the study seroimmune women were noted to have CMV reinfection during follow up [69]. A recent review of the literature indicated that the incidence of congenital CMV infection increases with increasing maternal CMV seroprevalence [68]. The positive correlation between higher maternal seroprevalence and high birth prevalence may seem paradoxical because this suggests that a smaller number of pregnant women are at risk for primary infection. However, in a high seroprevalence population, the number of pregnancies at risk for reactivation is also increased. In addition, the high seroprevalence may be due to a higher prevalence of risky behaviors in the population. In a high seroprevalence population, a pregnant woman has a higher likelihood of exposure to CMV-infected people. Thus, in a high risk population, seropositive women have a higher risk of reactivation and seronegative women have a higher risk of primary infection [70]. Preventive measures should be taken to decrease perinatal mortality and morbidity related to CMV infection and to ensure that women are not infected with CMV during pregnancy. Pregnant women should be consulted and encouraged to implement these preventive measures. Routine nationwide screenings for this condition should be considered, although serious cost effectiveness issues need to be evaluated before the implementation of such screenings.

In Kirkuk, CMV seroprevalence is as high as 92.1\%. Routine CMV screening in such a population is unnecessary, but there are exceptions. Pregnant women who had contact with a patient with a proven acute 
CMV infection, as well as patients with upper respiratory system infection-like symptoms, hepatomegaly, elevated liver enzymes, lymphadenopathy and immunocompromised statuses should all receive screening [20]. Thus, a routine screening test is usually justified only for conditions with an expected high rate of infection, conditions that have a proven mode of prevention and conditions where the screening method is safe and inexpensive [53]. At this time, routine screening for CMV is not recommended given the high seropositivity prevalence. Because there is no consistently effective treatment for congenital CMV infection available, the testing is clinically useless and expensive. However, Nigro et al. [71] recently reported promising results concerning passive immunization against congenital CMV infection.

In the current study there was a significant $\left(\mathrm{X}^{2}=6.82, \mathrm{P}=0.007\right)$ difference in CMV seroprevalence between pregnant $(94.2 \%)$ and non pregnant $(87.8 \%)$ women with bad obstetric history. In addition, there was a significant difference between pregnant (90\%) and non pregnant $(97.4 \%)$ women with previous normal pregnancy $\left(\mathrm{X}^{2}=6.76, \mathrm{P}=0.008\right)$. Furthermore, CMV-IgG seroprevalence was not significantly $\left(\mathrm{X}^{2}=0.6\right.$, $\mathrm{P}>0.05)$ different in non pregnant $(91.4 \%)$ from that in pregnant $(92.8 \%)$ women.

CMV-IgG seroprevalence among our study population women ranged from $87.4 \%$ to $95.6 \%$ across age groups and shows a significant trends with age $\left(\mathrm{X}^{2}=9.21, \mathrm{P}=0.027\right)$. However, there was a significant $\left(\mathrm{X}^{2}=4.32-9.51, \mathrm{P}=0.038-0.002\right)$ differences in seroprevalence between women with $\mathrm{BOH}$ and control among the age groups of 20-29,30-39, qnd 40-48. In addition, the women in the age group 30 and above years old had lower prevalence CMV-IgG $(87.4 \%, 229 / 262)$ as compared to women in the age of $<30$ years (94.7\%,270/285). This difference was significant as confirmed by OR calculation (OR=2.594, $\mathrm{P}=0.003)$. This trend was not consistent to a recently reported study in Kirkuk in which the rate was higher in women with age of $>30$ years [53]. The difference between the two studies was due to that the present study included only $\mathrm{BOH}$ group, while the recently reported study include $\mathrm{BOH}$ and control collected together. The CMV transmission variation in different age groups could be due to fact that as the women interaction and encounter with the risk factors tend to increase or decrease according to age [72] and social characters. Our finding was in consistent to that reported for other geographical areas [20],[47],[72],[73],[74]. Seroprevalence for CMV between the age of 15 to 19 years was too high (95.6\%). This high seroprevalence could be attributed to the widely practice of breastfeeding during infancy [75]. Breastfeeding is a common practice in Iraq and it is known to be a significant source of CMV transmission to children and plays an important role in the epidemiology of CMV infection as the virus is reactivated during lactation in nearly every seropositive mother [76]. In addition, close contacts and crowdness in the primary and secondary schools could contribute to such increase in CMV seroprevalence [77]. The antibody prevalence reduced $(94.6 \%)$ in the age group of $20-29$ years. This finding was not agreed to that reported for USA, in which seroprevalence increased steadily with age [78], but agreed with that reported for Portugal [74]. Studies with similar age groups conducted in other countries, such as USA, Japan, France, England, Poland, and Russia, describe seroprevalences ranging between 51.5\% and 78\% [40],[79]-[84].

The seroprevalence of women with CMV-IgG gradually reduced in the two oldest age groups, with values of $87.4 \%$ and $87.5 \%$, suggesting that sexual transmission was an important route of transmission of the virus in the population [85]. Another recognized source of adult CMV infection are children. CMV infected children shed virus in saliva and urine for years, providing an opportunity for continued spread to other children and susceptible adults (close relative, teachers) [86],[87].

Nevertheless, it should be noted that in our study, $7.2 \%$ of the pregnant women were susceptible to CMV, a finding that was not significantly different from that recently reported (6.5\%) for Kirkuk [53]. In addition, $5.8 \%$ of pregnant women was with current infection, which let us to conclude that there is a considerable risk for congenital infection due to maternal primary CMV infection, which leads to fetal infection in approximately $40 \%$ of cases ( $6 \%$ congenital infection in our cohort) [88]. However, this rate of current infection was lower to that reported for Kirkuk $(9.6 \%)$ recently, which indicating a reduction in primary CMV infection. In this risk group (women with primary CMV), we must apply the approaches to prevent congenital CMV infections, which include improved hygiene behavior, of seronegative women, administration of hyperimmune globulin to pregnant women with primary infection or pregnant women with previous infection who demonstrated CMV antibody titers or low IgG avidity [89].

Child-to-mother transmission of CMV during pregnancy in seronegative women could be controlled or prevented through simple hygiene such as frequent hand washing, wearing gloves for specific childcare tasks and avoiding intimate contact with their child such as sharing utensils, food or towels, and kissing on or near mouth [90]-[92].

Despite advances in the diagnosis of maternal-fetal CMV infection and approaches to prevent congenital $\mathrm{CMV}$, an effective prenatal therapy is unavailable. A prospective, non-randomised study of pregnant women who acquired CMV infection during pregnancy and who received passive immunisation with CMV HIG, showed that this therapy was associated with a significantly reduced risk of congenital CMV disease and infection and had no adverse effects [89],[93],[94]. Recent case reports supported safe

Association Between Cytomegalovirus Infection and Bad Obstetric Outcomes in Women (Hala Mohamed) 
administration of oral ganciclovir to mothers of CMV-infected fetuses, with no teratogenic side effects when given in the early stages of pregnancy [89],[95],[96]. The efficacy of ganciclovir still remains to be defined in controlled trials. Other early experience with treatment of intrauterine CMV infection using maternal oral administration of valaciclovir showed that it decreased the viral load in fetal blood significantly and could potentially also reduce the morbidity of prolonged intrauterine infection [97]. The absence of adverse effects or teratogenecity of valaciclovir is compatible with its clinical use, but a well designed randomised controlled trial is needed. Currently, there is no approved vaccine for CMV, but two vaccines are in phase II studies: one is a recombinant vaccine containing the major envelope glycoprotein B of the virus with the adjuvant MF59 (gB/MF59) that induces high levels of neutralising antibodies, is safe and immunogenic in adults and infants, preventing also maternal CMV infection [98],[99]. The other vaccine is the live attenuated CMV Towne strain that stimulates neutralising antibodies comparable to those induced by wild type virus and protects renal transplant patients from severe CMV after transplantation [93],[100].

The main interventions for the prevention of CMV infection should be aimed at women who wish to become pregnant, women who care for children and immunocompromised individuals. These individuals in whom exposure to CMV can be most detrimental will be the target groups for possible administration of a future vaccine [74].

From this study, rural residents had the higher CMV-IgG prevalence of $92 \%$, while urban residents CMV - IgG seroprevalence was $90.9 \% \quad\left(\mathrm{X}^{2}=0.169, \quad \mathrm{P}>0.05\right)$. The association between CMV-IgG seroprevalence and residence was not confirmed by $O R$ calculation $(\mathrm{OR}=0.872, \mathrm{P}>0.05)$ which not agrees with the statement that low socio-economic status has been found as a strong risk factor for acquisition of CMV infection [101]. Our finding was in agreement with that reported recently for Kirkuk [53] and that reported for other geographical areas [72],[102].

In relation to educational status, $\mathrm{CMV}-\mathrm{IgG}$ seroprevalence was significantly lower in uneducated $(86.6 \%)$ as compared to educated women $(92.8 \%)\left(\mathrm{X}^{2}=4.33, \mathrm{P}=0.037\right)$. OR confirm the association between $\mathrm{CMV}$-IgG seroprevalence and educated women $(\mathrm{OR}=2.003, \mathrm{P}=0.026)$. This finding was not in agreement to that reported for other countries [47,72][41,60] and recently reported for Kirkuk [53]. Illiteracy and low education levels were observed before as risk factors for increased susceptibility to acquisition of CMV infection, perhaps through the direct contact with contagious secretions from their own children and poor hygiene practiced by these women [101],[103]-[105].

Likewise, low socioeconomic status has been found as a strong risk factor for acquisition CMV infection [101]. Nevertheless in Iraq it is difficult to investigate the socio-economic status of these pregnant women because the culture is based on generous hospitality attitude toward guest and family members who usually lives in extended families [53].

There was no difference in prevalence of CMV-IgG amongst working women (91.1\%) as compared to housewife (91.2\%) women. Using bivariate analyses, OR not confirmed a significant association between occupation and CMV-IgG seroprevalence. This finding agreed to that reported by others [53],[72]. In contrast, a reported study indicated that CMV-IgG seropositivity was more in housewife women occupation as compared to others [44].

The present study shows a lower CMV-IgG seroprevalence in large size families (crowding index $>3)(75.2 \%)$, than that in small size families $(98.2 \%)\left(\mathrm{X}^{2}=73.4, \mathrm{P}=0.000\right)$. OR confirmed the association between crowding index and $\mathrm{CMV}-\mathrm{IgG}$ seropositivity $(\mathrm{OR}=17.713, \mathrm{P}=<0.0001)$ a finding not agreed to that reported by others [53],[104]. Housing crowdedness and family size are imperfect measures of the transmission dynamics that actually determine an individual's risk of exposure [105]. No significant association was found between the prevalence of $\mathrm{BOH}$ due to CMV infection and a mean household size of more than 3.0 persons. Previous studies suggest a positive correlation of congenital CMV with a household size more than three persons and low socioeconomic status [87],[106]-[108].

CMV IgM seroprevalence among women included in this study was $4.1 \%$ and vary significantly between pregnant $(5.8 \%)$ and non pregnant $(2.2 \%)$ women $\left(\mathrm{X}^{2}=6.85, \mathrm{P}=0.007\right)$. Although, CMV IgM seroprevalence was lower in women with bad obstetric history $(3.8 \%)$ as compared to women with normal pregnancy $(4.5 \%)$, but the difference was not significant. However, current infection of $4.1 \%$ and $7.2 \%$ seronegative in pregnant women represent a high rate of hazard for foetal infection. The current infection was lower $(4.1 \%)$ than that reported recently $(6.3 \%)$ for Kirkuk [53] indicating a decline in transmission of the virus in studied population.

Globally reported CMV IgM seropositivity range was from $0 \%$ for Turkey [19] to $13 \%$ for Poland [39] in pregnant women and from $0 \%$ for India [33] to $8.42 \%$ for India [13]. In Arab countries, the range of CMV IgM seropositivity was from $2.3 \%$ for Jordan [15] to 57.2 for Babylon, Iraq [14] in pregnant women, while to range in women with $\mathrm{BOH}$ was from $1.4 \%$ for Jordan [15] to $60.2 \%$ for Waset, Iraq [54]. Thus the present study finding for both women with normal pregnancy $(4.5 \%)$ and with $\mathrm{BOH}(3.8 \%)$ lay within the reported ranges for global areas and for Arab countries. However, the current CMV infection in our study 
was lower to that reported for Waset [54], Babylon [14], Diwaniya [61], Mosul [109], Baghdad [55],[60],[110], Al-Hila [56], Thi Qar [58,62] and Kirkuk [59],[53].

CMV IgM seroprevalence varied by age $\left(\mathrm{X}^{2}=0.88, \mathrm{P}>0.05\right)$, with a highest rate of current infection $(4.2 \%)$ in younger age $(<30 \mathrm{yrs})$ as compared to elder $(>30 \mathrm{yrs})\left(3.4 \%, \mathrm{X}^{2}=0.22, \mathrm{P}>0.05\right)$. This finding agreed with previous studies which showed that elderly persons seem to be well protected against CMV infection due to accumulation of $\mathrm{CD} 28$ effector cytotoxic T lymphocytes [72]. This is a characteristic feature of all age groups but is most pronounced in elderly persons [111]. However, there is a lot of debate concerning maternal age and CMV infection; while many investigators observed that, elder women were at higher risk of CMV infection [72],[101], others reported the reverse [30] or absence of variation by age [78]. All of the above findings are consistent with the understanding that CMV IgM can be produced throughout life after primary infection or as a result of reinfection or reactivation [112],[13], and suggest that in some older cohorts may be as likely to have a recurrent episodes as younger people are to have a primary infection [78].

The present study finding indicated a significant differences in recent infections between control and women with $\mathrm{BOH}$, who were with age of 20-29 $\left(\mathrm{X}^{2}=4.43, \mathrm{P}=0.03\right)$ and $30-39\left(\mathrm{X}^{2}=7.3, \mathrm{P}=0.007\right)$. this findings could be attributed to the age of marriage in Iraq (around 20 years) and sexual activity.

Risk factors based on residence ( $\mathrm{OR}=29.71, \mathrm{P}=0.01)$, emerged for $\mathrm{CMV}$ IgM seroprevalence in contrast to education, age, crowding index, occupation, smoking, haemoglobin level, animal exposure, number of abortion and congenital anomalies. Staras et al [79] not reported age as a risk for CMV IgM seropositivity, but confirmed the age as risk for CMV IgG seropositivity. The lack of identifiable risk factors for CMV IgM may be due to relatively low number of observations, and because over $80 \%$ of the IgM reactivity in tested sample was with high avidity and thus presumably from non primary CMV infection, which may be less associated with identifiable risk than primary infection [78]. In addition, a portion of the IgM positive sera may have been false positive determinations known to occur with CMV IgM testing [114].

The current CMV infection was more predominant in urban women $\left(5.6 \% ; \mathrm{X}^{2}=10.18, \mathrm{P}=0.000\right)$ ), and this finding was agreed to that reported for Kirkuk [53] and not consistent with previously reported studies [72],[110],[115]. In addition, there were no significant differences in current CMV infection in regards to occupation, education, family size, smoking, haemoglobin level, number of abortion and congenital anomalies as OR was not significant. However, current infection was with significant differences between who exposed to animal and not exposed women $\left(\mathrm{X}^{2}=8.99, \mathrm{P}=0.001\right)$. Kolo et al [72] reported a high prevalence of CMV IgM in pregnant women with primary education, which agrees with the reports from United States and Western Europe.

The present study indicated a high CMV IgG seroprevalence (94.2\%) in women with $\mathrm{BOH}$ who were smoking $\left(\mathrm{X}^{2}=8.93, \mathrm{P}=0.003\right)$ as compared to non smoking $(86.8 \%)$. OR confirmed that smoking was a risk factor for development of $\mathrm{BOH}$ in women infected previously with $\mathrm{CMV}$. This could be explained on the basis that smoking may reactivate the latent CMV infection, a hypothesis that need a future research to confirm such association. Cigarette smoke was shown to augment the production of numerous proinflammatory cytokines and to decrease the levels of anti-inflammatory cytokines [116]-[118]. In addition, smoking may play a role in the process of autoimmune disorders as reported in rheumatoid arthritis and systemic lupus erythematosus [117], this phenomenon could be present in cases of abortion.

Most of the reported studies have addressed the risk of spontaneous abortion in relation to smoking during pregnancy, however, results are not entirely consistent [119],[120]. The amount of daily smoking prior to pregnancy seems to be associated with an increased risk of spontaneous abortion, where as the duration of smoking does not seem to be related to an increased risk of spontaneous abortion [120]. The present study demonstrated a significant association between presence of CMV IgG positivity and smoking. Thus smoking could be a risk factor for CMV infection. However, this need to be evaluated in a study that take in consideration the amount of smoking.

This study shows a higher (92.1\%) CMV IgG seroprevalence in $\mathrm{BOH}$ women with haemoglobin level of $<11$ as compared to those with haemoglobin of $>11(90.9 \%)$, but the difference was not significant $\left(\mathrm{X}^{2}=0.06, \mathrm{P}>0.05\right)$. OR not confirmed that iron deficiency anaemia as risk factor for BOH development in women infected with CMV. Anemia is a global public health problem. It has serious short- and long-term consequences during pregnancy and beyond. The anemic condition is often worsened by the presence of other chronic diseases. Untreated anemia also leads to increased morbidity and mortality from these chronic conditions as well [121]. In the present study we are not sure whether the anaemia was a consequence of the CMV chronicity or the anaemia may be a risk factor for the development of CMV infection. This could be evaluated in a follow up study during pregnancy of a negative CMV pregnant.

The exact mechanism by which anemia is caused in chronic inflammatory conditions is unknown. A common factor may be the contribution of hepcidin, a polypeptide hormone. Chronic inflammatory conditions lead to release of cytokines from the reticuloendothelial system as a part of cell-mediated immunity. In response to these cytokines, mainly interleukin 6 (IL-6) [122],[123], the liver produces 
increased amounts of hepcidin, which in turn prevents release of iron from its stores. The process is mediated by blocking iron channels (such as ferroportin). Inflammatory cytokines also appear to influence other important aspects of iron metabolism, such as decreasing ferroportin expression, and possibly directly suppressing erythropoiesis by decreasing the ability of the bone marrow to respond to erythropoietin [124].

The present study indicated a higher $(92.8 \%)$ CMV IgG seroprevalence in women exposed compared to those who not exposed (90.4\%) to animals, however, the difference was not significant. There was no report present in the literature that described the association between animal exposure and CMV infection. While CMV is considered to be species specific, research group previously showed that baboon CMV can replicate on human fibroblasts in vitro [125]. The high positivity in exposed as compared to none exposed to animals may be due to presence of cross reactivity between HCMV and animal CMV.

CMV IgG seroprevalence was significantly $\left(\mathrm{X}^{2}=6.1, \mathrm{P}=0.01\right)$ lower $(89.5 \%)$ in women with frequent abortion (3-8) as compared to women (97.4\%) non frequent abortion (1-2). OR confirmed the association between CMV IgG seroprevalence and number of abortion $(\mathrm{OR}=4.39, \mathrm{P}=0.01)$. However, $\mathrm{CMV}$ IgG seroprevalence was higher $(95.9 \%)$ in women with congenital anomalies pregnancy outcome as compared to those without $(90.8 \%)$, but the difference not reach significant level $\left(\mathrm{X}^{2}=.48, \mathrm{P}>0.05\right)$. OR not confirmed as association between CMV IgG seroprevalence and development of congenital anomalies $(\mathrm{OR}=0.418, \mathrm{p}>0.05)$.

The high rate of CMV seroprevalence in women with low number of abortion may be a reflection of the high viraemia in primary infection. Then CMV antibodies waned with time so the seropositivity reduced and demonstrate a low seroprevalence of CMV IgG.

\section{REFERENCES}

[1] Paschale De M, Carlo A, Maria T, Alessia P, Pierangelo C. "Incidence and Risk of Cytomegalovirus Infection during Pregnancy in an Urban Area of Northern Italy", Infectious Diseases in Obstetrics and Gynecology, 2009. Article ID 206505, 5 pages doi:10.1155/2009/206505

[2] Rubina FA. Bashir TM, Tehmeena W, Dalip K, Rubina S, Asifa N. "Seroprevalence of Cytomegalovirus(CMV)in Kashmir valley: A preliminary study”, J K Practitioner, Vol. 11. Pp. 261-262, 2004.

[3] Mocarski E S. Cytomegaloviruses and their replication. Fields Virology. 3r ed. Fields BN, Knipe DM, Howley PM, Chanock RM. Melnick JL, Monath TP, Roizman B and Straus SE eds. Lippincott-Raven, Philadelphia. Pp. 2447-2492, 1996.

[4] Nahum A, Dadi H, Bates A, Roifman CM. "The biological significance of TLR3 variant, L412F, in conferring susceptibility to cutaneous candidiasis, CMV and autoimmunity", Autoimmun Rev, Vol. 11. Pp. 341-7, 2012.

[5] Fairly J A, Baillie J, Bain M and Sinclair J H. "Human cytomegalovirus infection inhibits epidermal growth factor (EGF) signaling by targeting EOF receptors", J Gen Virol, Vol. 83. Pp. 2803-2810, 2002.

[6] Fowler K B and Pass R F. "Sexually transmitted diseases in mothers of neonates with congenital cytomegalovirus infection", J Infect Dis, Vol. 164. Pp. 259-264, 1991.

[7] Stagno S, Pass RF, Dworsky ME, Henderson RE, Moore EG, Walton PD, et al. "Congenital cytomegalovirus infection: the relative importance of primary and recurrent maternal infection", New Eng J Med, Vol/Issue: 306(16). Pp. 945-949, 1982.

[8] Adler SP. "Screening for cytomegalovirus during pregnancy", Infect Dis Obes Gynecol, Pp. 1-9, 2011. doi:10.1155/2011/942937

[9] Alsamarai AGM, Aljumaili ZK. "Seroepidemiology of Toxoplasma, Rubella, Cytomegalovirus and Herpes Simplex Virus -2 in Women with Bad Obstetric History. PART II. Cytomegalovirus and Herpes Simplex Virus Infections", Our Dermatology, Vol. 4. Pp. 536-544, 2013.

[10] Knowles SJ, Grundy KC, Cafferkey MT, et al. "Low cytomegalovirus seroprevalence in Irish pregnant women", Ir Med J, Vol. 98. Pp. 210-212, 2005.

[11] Koksaldi -Motor V, Evirgen O, Azaroglu I, Inci M, Ozer B, Arica S. "Prevalence of Toxoplasmosis, Cytomegalovirus and Rubella IgGAntibodies in Hatay Women and Children", West Indian Med J, Vol/Issue: 61(2). Pp. 154-157, 2012.

[12] Falahi S, Ravanshad M, Koohi AK, Karimi AM. "Short Communication: Seroprevalence of CMV in women's with spontaneous abortion in kowsar hospital, Ilam during 2007-2008”, Modares J Med Sci Pathobiology, Vol. 12. Pp. 39-43, 2010.

[13] Turbadkar D, Mathur M, Rele M. "Seroprevalence of TORCH infection in bad obstetric history", Indian J Med Microbiol, Vol. 21. Pp. 108-11, 2003.

[14] Al-Marzoqi AHM, Kadhim RA, Aljanabi DKF, Hussein HJ, Al Tae ZM. "Seroprevalence study of IgG and IgM Antibodies to Toxoplasma, Rubella, Cytomegalovirus, Chlamydia trachomatis and Herpes simplex II in Pregnancy women in Babylon Province", Journal of Biology, Agriculture and Healthcare, Vol. 2. Pp. 159-164, 2012.

[15] Daboubi M, Al-Zaben S. "Cytomegalovirus infection in women of childbearing age in Jordan", Jordan Med J, Vol. 34. Pp. 106-108, 2000.

[16] Abdul Mohymen N, Hussien A, Hassan FK. "Association between TORCH agents and recurrent spontaneous abortion”, Iraqi J Med Sci, Vol. 7. Pp. 40-46, 2009. 
[17] Uyar1 Y, Balci A, Akcali A, Cabar C. "Prevalence of rubella and cytomegalovirus antibodies among pregnant women in northern Turkey", New Microbiologica, Vol. 31. Pp. 451-455, 2008.

[18] Karabulut A, Polat Y, Turk M, Balci YI. "Evaluation of rubella, Toxoplasma gondii, and cytomegalovirus seroprevalences among pregnant women in Denizli province", Turk J Med Sci, Vol. 41. Pp. 159-164, 2011.

[19] Ozdemir M, Kalem F, Feyzioglu B, Bysal B. "Investigation of viral pathogen during pregnancyin a city region in Turkey”, Anatol J Clin Invest, Vol. 5. Pp. 78-81, 2011.

[20] Oruç AS, Çelen S, Çitil A, Saygan S, Ünlü S, Danişman N. "Screening of cytomegalovirus seroprevalence among pregnant women in Ankara, Turkey: A controversy in prenatal care”, Afr J Microbiol Res, Vol/Issue: 5(29). Pp. 5304-5307, 2011.

[21] Ocak S, Zeteroglu S, Ozer C, Dolapcioglu K, Gungoren A. "Seroprevalence of Toxoplasma gondii, rubella and cytomegalovirus among pregnant women in southern Turkey", Scand J Infect Dis, Vol. 39. Pp. 231-234, 2007.

[22] Tamer GS, Dundar D, Caliskan E. "Seroprevalence of Toxoplasma gondii, rubella and cytomegalovirus among pregnant women in western region of Turkey", Clin Invest Med, Vol. 32. Pp. E43-47, 2007.

[23] Akinbami AA, Rabiu KA, Adewunmi AA, Wright KO, Dosunmu AO, et al. "Seroprevalence of cytomegalovirus antibodies amongst normal pregnant women in Nigeria”, Int $J$ Womens Health, Vol. 3. Pp. 423-428, 2011.

[24] Ahmad RM, AH Kawo, TKC Udeani, SB Manga, ML Ibrahim, B Danjuma. "Sero-Prevalence of Cytomegalo Virus Antibodies in Pregnant Women Attending Two Selected Hospitals in Sokoto State, North-Western Nigeria", Bayero Journal of Pure and Applied Sciences, Vol/Issue: 4(1). Pp. 63 - 66.

[25] Yamamoto AY, Castellucci RAC, Mussi-Pinhata MM. "Early high CMV seroprevalence in pregnant women from a population with a high rate of congenital infection”, Epidemiol Infect, Vol. 3. Pp. 1-5, 2012.

[26] Arabpour M, Kaviyanee K, Jankhah A, Yaghobi R. "Human cytomegalovirus infection in women of childbearing age throughout Fars Province - Iran: a population-based cohort study", Malaysian Journal of Microbiology, Vol/Issue: 3(2). Pp. 23-28, 2007.

[27] Tabatabaee M, Tayyebi D. "Seroepidemiologic study of human cytomegalovirus in pregnant women in Valiasr Hospital of Kazeroon, Fars, Iran", J Maternal-Fetal Neonatal Med, Vol. 22. Pp. 517-521, 2009.

[28] Nabi SN, Wasey A, Haider KMTS, Khan AA, Hoque MM. "Seroprevalen of TORCH antibody in pregnant women", J Armed Forces Med Coll, Vol. 8. Pp. 35-39, 2012.

[29] Seo S, Cho Y, Park J. "Serologic screening of pregnant Korean women for primary human cytomegalovirus infection using IgG avidity test”, Korean J Lab Med, Vol/Issue: 29(6). Pp. 557-62, 2009.

[30] Correa CB, Kourí V, Verdasquera D, Martínez PA, Alvarez A, Alemán Y, Pérez L, Viera J, González R, Pérez E, Moro I, Navarro MA, Melin P. "HCMV seroprevalence and associated risk factors in pregnant women, Havana city, 2007 to 2008", Prenatol Diagn, Vol. 30. Pp. 888, 2010.

[31] Picone O, Vauloup-Fellous C, Cordier AG, Parent Du Châtelet I, Senat MV, Frydman R, Grangeot-Keros L. "A 2-year study on cytomegalovirus infection during pregnancy in a French hospital”, BJOG, Vol/Issue: 116(6). Pp. 818-23, 2009.

[32] Kumari N, Morris N, Dutta R. "Is screening of TORCH worthwhile in women with bad obstetric history: an observation from eastern Nepal”, J Health, PopNutr, Vol/Issue: 29(1). Pp. 77-80, 2011.

[33] Sadik MS, Fatima H, Jamil K, Patil C. "Study of TORCH profile in patients with bad obstetric history", Biology Medicine, Vol. 4. Pp. 95-101, 2012.

[34] Das S, Ramachandran VG, Arora R. "Cytomegalovirus and rubella infection in children and pregnant mothers-a hospital based study", J Commun Dis, Vol. 39. Pp. 113-117, 2007.

[35] Frischknecht F, Sell W, Trummer I, Bruhwiler H. "Serological testing for infectious diseases in pregnant women: are the guidelines followed?”, Swiss Med Wkly, Vol. 140. Pp. w131-38, 2011.

[36] McCabe R, Remington JS. “Toxoplasmosis, the time has come”, New Eng J Med, Vol. 318. Pp. 313-315, 1988.

[37] Sarawathy TS, Az-Ulhusna AA, Nurul R, Ashikin RN, Suriani SS, Zainah SS. "Seroprevalence of cytomegalovirus infection in pregnant women and associated role in obstetric complications: a preliminary study", Southeast Asian J Trop Med Public Health, Vol/Issue: 42(2). Pp. 320-2, 2011.

[38] Ebadi P, Solhjoo K, Bagheri K, Eftekhar F. "Seroprevalence of toxoplasmosis among the women with recurrent spontaneous abortion in comparison with the women with uncomplicated delivery", J Jahrom Uni Med Sci, Vol. 9. Pp. 32-36, 2011.

[39] Gaj Z, Rycel M, Wilczyński, Nowakowska D. "Seroprevalence of cytomegalovirus infection in the population of Polish pregnant women", Ginekol Pol, Vol/Issue: 83(5). Pp. 337-41, 2012.

[40] Odland JØ, Sergejeva IV, Ivaneev MD, Jensen IP, Stray-Pedersen B. "Seropositivity of cytomegalovirus, parvovirus and rubella in pregnant women and recurrent aborters in LeningChen $\mathrm{MH}$, Chen PCrad County, Russia”, Acta Obstet Gynecol Scand, Vol/Issue: 80(11). Pp. 1025-9, 2001.

[41] Jeng SF, Hsieh CJ, Su FC, Liao HF, Su YN, Lin SJ, Hsieh WS. "High perinatal seroprevalence of cytomegalovirus in northern Taiwan", J Paediatr Child Health, Vol/Issue: 44(4). Pp. 166-9, 2008.

[42] Enders G, Daiminger A, Lindemann , Knotek F, Bäder U, Exler S, Enders M. "Cytomegalovirus (CMV) seroprevalence in pregnant women, bone marrow donors and adolescents in Germany, 1996-2010", Med Microbiol Immunol, Vol. 201. Pp. 303-9, 2012.

[43] Rajaii1 M, Pourhassan A. "Evaluation of immunity against CMV in Azarbaijan female population", Iranian J Clin Infect Dis, Vol/Issue: 3(3). Pp. 143-148, 2008.

[44] Ashrafunnessa, Shahla S Khatun, Mohammad Nazrul MN Islam, M H MH Rashid. "Seroprevalence of cytomegalovirus antibody in antenatal population in Bangladesh", Bangladesh Med Res Counc Bull, Vol/Issue: 35(3). Pp. 110-2, 2009. 
[45] Inagaki ADM, Oliveira LAR, Oliveira MFB, Santos RCS, Araujo RM, et al. "Seroprevalence of antibodies for Toxoplasmosis, rubella, cytomegalovirus, syphilis and HIV among women in Serjipe", Rev. Soc. Bras. Med. Trop, Vol. 42, 2009.

[46] Hammouda NA, ElGebaly WM, Sadaka SM. "Seroprevalence of toxoplasma and cytomegalovirus in complicated pregnancies”, J Egypt Soc Parasitol, Vol. 23. Pp. 865-870, 1993.

[47] Kombich JJ, Muchai PC, Borus PK. "Seroprevalence of Natural Rubella Antibodies among Antenatal Attendees at Moi Teaching and Referral Hospital, Eldoret, Kenya", J Infect Dis Immunol Tech, Vol 1, 2011. doi:10.4172/2325-9752.1000102

[48] Barah F. "Prevalence of herpes simplex types 1 and 2, varicella zoster virus, cytomegalovirus, immunoglobulin G antibodies among female university students in Syria", Saudi Med J, Vol. 33. Pp. 990-994, 2012.

[49] Ghazi, HO, Telmesani, AM, Mahomed, MF. "Torch agents in pregnant Saudi women", Med. Princ. Pract, Vol/Issue: 11(4). Pp. 180-90, 2002.

[50] Abu-Madi MA, Behnke JM, Dabritz HA. "Toxoplasma gondii seropositivity and co-infection with TORCH pathogens in high-risk patients from Qatar", Am J Trop Med Hyg. Vol/Issue: 82(4). Pp. 626-33, 2010.

[51] Kafi S, Eldouma E, Saeed S, Musa H. "Seroprevalence of Cytomegalovirus among blood donors and antenatal women attending two hospitals in Khartoum State", Sudan J. Med. Sci,Vol. 4. Pp. 399-401, 2009.

[52] Hananchi N, Marzouk M, Harrabi I, Ferjani A, Ksouri Z, et al. "Seroprevalence of rubella virus, varicella zoster virus, cytomegalovirus and parvovirus B19 among pregnant women in the Sousse region, Tunisia", Bull Soc Pathol Exot, Vol. 104. Pp. 62-67, 2011.

[53] Aljumaili ZKM, Alsamarai AGM, Najem WS. "Cytomegalovirus seroprevalence in women with bad obstetric history in Kirkuk, Iraq", J Infection Public Health, 2013.

[54] Jasim M, Majeed HA, Ali AI. "Performance of Serological Diagnosis of TORCH Agents in Aborted versus non aborted Women of Waset province in Iraq", Tikrit Medical Journal, Vol/Issue: 17(2). Pp. 141-147, 2011.

[55] Majeed AK. "Toxoplasma gondii and cytomegalovirus seropositivity pathogens in high- risk patients in Iraq", AlAnbar J. Vet. Sci, Vol. 4. Pp. 45-49, 2011.

[56] Alsaeed MS, Muhsen MA, Al-Juburi GJ. "Study the role of Toxoplasma gondii, Cytomegalovirus and antiphospholipids antibodies in cases of abortion among women in Hilla city", Q Med J, Vol. 4. Pp. 1-8, 2008.

[57] Almishhadani JI, Aljanabi AU. "Toxoplasmosis and Cytomegalovirus Infection among Aborted Women in A1Anbar Governorate", 2008.

[58] Al-Khafaji AH, Al-Zubaidi KI. "Seroprevalence of cytomegalovirus infection among aborted women in Thi-Qar Governorate", J Thi- Qar Sci, Vol. 2. Pp. 20-26, 2010.

[59] Salman YG. "Serological Cross Reaction among Some Causative Agents of Women Abortions (Toxoplasma gondii \& Cytomegalovirus \& Rubella Virus), with the Incidence of Hepatitis Virus (B \&C)", Tik J Pharm Sci, Vol. 3. Pp. 102-111, 2007.

[60] Al-Azzawi RHM. "Seroprevalence of cytomegalovirus infectionin premarital women in some Baghdad hospitals", Iraqi J Sci, Vol. 53. Pp. 40-45, 2012.

[61] Al-Shimmery MN, Al-Hilaly HA, Al-Khafaji AA. "Seroprevalence of cytomegalovirus and toxoplasmosis in cases of miscarriages women in Al-Diwaniyah province”, Al-Qadisiah Med J, Vol. 7. Pp. 160-168, 2011.

[62] Hadi NJ. "Prevalence of Antibodies to Cytomegalovirus, Rubella Virus and Toxoplasma gondii among aborted women in Thiqar province", J Educ Coll, Vol. 1. Pp. 3-9, 2011.

[63] Mussi-Pinhata MM, Yamamoto AY, Moura Brito RM, et al. "Birth prevalence and natural history of congenital cytomegalovirus infection in a highly seroimmune population", Clin Infect Dis, Vol. 49. Pp. 522-528, 2009.

[64] Boppana SB, Rivera LB, Fowler KB, Mach M, Britt WJ. "Intrauterine transmission of cytomegalovirus to infants of women with preconceptional immunity”, N Engl J Med, Vol. 344. Pp. 1366-1371, 2001.

[65] Ahlfors K, Ivarsson SA, Harris S. "Secondary maternal cytomegalovirus infection-a significant cause of congenital disease", Pediatrics, Vol. 107. Pp. 1227-1228, 2001.

[66] Ross SA, Fowler KB, Ashrith G, et al. "Hearing loss in children with congenital cytomegalovirus infection born to mothers with preexisting immunity", J Pediatr, Vol. 148. Pp. 332-336, 2006.

[67] Dar L, Pati SK, Patro AR, et al. "Congenital cytomegalovirus infection in a highly seropositive semi-urban population in India", Pediatr Infect Dis J, Vol. 27. Pp. 841-843, 2008.

[68] Bakıcı MZ, Nefesoğlu N, Erandaç M. "The assessment of results of TORCH screening among patients' sera samples that run at C.U. Microbiology Laboratory for a year. C.Ü”, Tıp Fakültesi Derg, Vol. 24. Pp. 5-8, 2002.

[69] Ross SA, Arora N, Novak Z, Fowler KB, Britt WJ, Boppana SB. "Cytomegalovirus re-infections in healthy seroimmune women", J Infect Dis, Vol. 201. Pp. 386-9, 2010.

[70] Kenneson A, Cannon MJ. "Review and meta-analysis of the epidemiology of congenital Cytomegalovirus (CMV) infection", Rev. Med. Virol, Vol. 17. Pp. 253-76, 2007.

[71] Nigro G, Adler SP, Torre RL. "Passive immunization during pregnancy for congenital CMV infection", N. Engl. J. Med, Vol. 353. Pp. 1350-1362, 2005.

[72] Kolo RL, Umoh J, Jatau ED, Ella EE. "Seroprevalence of cytomegalovirus among antenatal patients attending primary health centres in some parts of Kaduna State, Nigeria", SAJEB, Vol. 3. Pp. 43-48, 2013.

[73] Bagheri L, Mokhtarian H, Sarshar N, Ghahramani M. "Seroprevalence of cytomegalovirus infection among pregnant women in Eastern Iran”, Braz J Infect Dis, Vol. 16. Pp. 402-403, 2012.

[74] Lopo S, Vinagre E, Palminha P, Paixao MT, Nogueira P, Freitas MG. "Seroprevalence to cytomegalovirus in Portuguese population, 2002-2003”, Euro Surveill, Vol. 16. Pp. 1-6, 2011. 
[75] Pass RF. "A key role for adolescents in the epidemiology of cytomegalovirus and genital herpes infections", Clin Infect Dis, Vol/Issue: 39(10). Pp. 1439-40, 2004.

[76] Arvin AM, Fast P, Myers M, Plotkin S, Rabinovich R. "Vaccine development to prevent cytomegalovirus disease: report from the National Vaccine Advisory Committee", Vaccines Clin Infect Dis, Vol/Issue: 39(2). Pp. 233-9, 2004.

[77] Hamprecht K, Maschmann J, Jahn G, Poets CF, Goelz R. "Cytomegalovirus transmission to preterm infants during lactation”, J Clin Virol, Vol/Issue: 41(3). Pp. 198-205, 2008.

[78] Dollard SC, Staras SAS, Amin MM, Schmid DS, Cannon MJ. "National Prevalence Estimates for Cytomegalovirus IgM and IgG Avidity and Association between High IgM Antibody Titer and Low IgG Avidity", Clin Vaccine Immunol, Pp. 1895-1899, 2011.

[79] Staras SA, Dollard SC, Radford KW, Flanders WD, Pass RF, Cannon MJ. "Seroprevalence of cytomegalovirus infection in the United States, 1988-1994”, Clin Infect Dis, Vol/Issue: 43(9). Pp. 1143-51, 2006.

[80] Takeda N, Isonuma H, Sekiya S, Ebe T, Matsumoto T, Watanabe K. "Studies of anti-cytomegalovirus IgG antibody positive rate and cytomegalovirus mononucleosis in adults", Kansenshogaku Zasshi, Vol/Issue: 75(9). Pp. 775-9, 2001.

[81] Gratacap-Cavallier B, Bosson J, Morand P, Dutertre N, Chanzy B, Seigneurin J, et al. "Cytomegalovirus seroprevalence in French pregnant women: parity and place of birth as major predictive factors", Eur J Epidemiol Vol/Issue: 14(2). Pp. 147-52, 1998.

[82] Tookey P, Ades A, Peckham C. "Cytomegalovirus prevalence in pregnant women: the influence of parity", Arch Dis Child, Vol/Issue: 67(7). Pp. 779-83, 1992.

[83] Nishimura N, Kimura H, Yabuta Y, Tanaka N, Ito Y, Morishima T, et al. "Prevalence of maternal cytomegalovirus (CMV) antibody and detection of CMV DNA in amniotic fluid", Microbiol Immunol, Vol/Issue: 43(8). Pp. 781-4, 1999.

[84] Karas Z, Blok R, Zabel J, Zaba C. "Seroepidemiologic study of cytomegaly and rubella in pregnant women and prostitutes", Przegl Epidemiol, Vol/Issue: 46(4). Pp. 303-7, 1992.

[85] Staras S, Flanders WD, Dollard SC, Pass RF, McGowan JE, Cannon MJ. "Influence of sexual activity on cytomegalovirus seroprevalence in the United States, 1988-1994", Sex Transm Dis, Vol/Issue: 35(5). Pp. 42-9, 2008.

[86] Pass, RF. Cytomegalovirus. In: Knipe DM, Howley PM, editors. Fields' Virology. 4th ed. Philadelphia: Lippincott Williams \& Wilkins. Pp. 2675-705, 2001.

[87] Fowler KB, Pass RF. "Risk factors for congenital cytomegalovirus infection in the offspring of young women: exposure to young children and recent onset of sexual activity", Pediatrics, Vol/Issue: 118(2). Pp. 286-92, 2006.

[88] Stagno S, Britt W. Cytomegalovirus infections. In: Remington JS, Klein JO, Wilson CB, Baker CJ, editors. Infectious Diseases of the Fetus and Newborn Infant. 6th ed. Philadelphia: Elsevier Saunders. Pp. 739-81, 2006.

[89] Adler SP, Nigro G, Pereira L. "Recent advances in the prevention and treatment of congenital cytomegalovirus infections", Semin Perinatol, Vol/Issue: 31(1). Pp. 10-8, 2007.

[90] Cannon MJ, Davis KF. "Washing our hands of the congenital cytomegalovirus disease epidemic", BMC Public Health, Vol. 5. Pp. 70, 2005.

[91] Centers for Disease Control and Prevention (CDC). Department of Health and Human Services (USA). About CMV - General information. 2006

[92] Ross DS, Dollard SC, Victor M, Sumartojo E, Cannon MJ. "The epidemiology and prevention of congenital cytomegalovirus infection and disease: activities of the Centers for Disease Control and Prevention Workgroup", $J$ Women Health (Larchmt), Vol/Issue: 15(3). Pp. 224-9, 2006.

[93] Adler SP. "Human CMV vaccine trials: what if CMV caused a rash?", J Clin Virol, Vol/Issue: 41(3). Pp. 231-6, 2008.

[94] Nigro G, Adler SP, La Torre R "Best AI. Congenital Cytomegalovirus Collaborating Group. Passive immunization during pregnancy for congenital cytomegalovirus infection", $N$ Engl J Med, Vol/Issue: 353(13). Pp. $1350-62,2005$

[95] Brady RC, Schleiss MR, Witte DP, Siddigi TA, Fame PT. "Placental transfer of ganciclovir in a woman with acquired immunodeficiency syndrome and cytomegalovirus disease", Pediatr Infect Dis J, Vol/Issue: 21(8). Pp. 796-7, 2002.

[96] Puliyanda DP, Silverman NS, Lehman D. "Successful use of oral ganciclovir for the treatment of intrauterine cytomegalovirus infection in a renal allograft recipient", Transplant Infect Dis, Vol/Issue: 7(2). Pp. 71-4, 2005.

[97] Jacquemard F, Yamamoto M, Costa J-M, Romand S, Jaqz-Aigrain E, Ville Y, et al. "Maternal administration of valaciclovir in symptomatic intrauterine cytomegalovirus infection”, BJOG, Vol/Issue: 114(9). Pp. 1113-21, 2007.

[98] Pass RF. "Development and evidence for efficacy of CMV glycoprotein B vaccine with MF59 adjuvant", J Clin Virol, Vol/Issue: 4(4). Pp. S73-6, 2009.

[99] Pass RF, Zhang C, Evans A, Simpson T, Andrews W, Cloud G, et al. "Vaccine prevention of maternal cytomegalovirus infection”, N Engl J Med, Vol/Issue: 360(12). Pp. 1191-9, 2009.

[100] Griffiths PD. “CMV vaccine trial endpoints”, J Clin Virol, Vol/Issue: 46(4). Pp. S64-7, 2009.

[101] Bate SL, Dollard SC, Cannon MJ. "Cytomegalovirus seroprevalence in the United States: the national health and nutrition examination surveys, 1988- 2004”, Clin Infect Dis, Vol/Issue: 50(11). Pp. 1439-47, 2010.

[102] Jindal SN, Aggarwal A. "A pilot seroepidemiological study of cytomegalovirus infection in women of childbearing age", Indian J Med Microbiol, Vol. 23. Pp. 34-36, 2005. 
[103] Kramer A, Schwebke I, Kampf G. "How long do nosocomial pathogens persist on inanimate surfaces? A systematic review”, BMC Infect Dis, Vol. 6. Pp. 130, 2006.

[104] Walmus BF, Yow MD, Lester JW, Leeds L, Thompson PK, Woodward RM. "Factors predictive of cytomegalovirus immune status in pregnant women", J Infect Dis, Vol. 157. Pp. 172-7, 1988.

[105] Dowd JB, Haan MN, Blythe L, Moore K, Aiello AE. "Socioeconomic gradients in immune response to latent infection", Am J Epidemiol, Vol/Issue: 167(1). Pp. 112-20, 2008.

[106] Kenneson A, Cannon MJ. "Review and meta-analysis of the epidemiology of congenital cytomegalovirus (CMV) infection", Reviews Med Virolo, Vol. 17. Pp. 253-276, 2007.

[107] Fowler KB, Stagno S, Pass RF. "Maternal age and congenital cytomegalovirus infection: Screening of two diverse newborn populations, 1980-1990", J Infect Dis, Vol. 68. Pp. 552-556, 1993.

[108] Fowler KB, Stagno S, Pass RF. "Maternal immunity and prevention of congenital cytomegalovirus infection", JAMA, Vol. 289. Pp. 1008-1011, 2003.

[109] AL - Taie AAD. "Serological Study For TORCH Infections In Women With High Delivery Risk Factors In Mosul”, Tikrit Journal of Pure Science, Vol. 15. Pp. 193-198, 2010.

[110] Khalf MS, Ahmad DW, Ibraheem KA. "The Seroprevalence of IgM Among Iraqi Aborted Women Infected with Human Cytomegalovirus”, Iraqi Postgrad Med J, Vol. 11. Pp. 123-129, 2012.

[111] Pedron B, Guerin V, Jacquemard F, Munier A, Daffos F, Thulliez F, Aujard Y, Luton D, Sterkers G. "Comparison of CD8+ T Cell Responses to Cytomegalovirus between Human Fetuses and Their Transmitter Mothers", J Infect Dis, Vol. 196. Pp. 1033-1043, 2007.

[112] Nielsen, S. L., I. Sorensen, and H. K. Andersen. "Kinetics of specific immunoglobulins M, E, A, and G in congenital, primary, and secondary cytomegalovirus infection studied by antibody-capture enzyme-linked immunosorbent assay”, J. Clin. Microbiol, Vol. 26. Pp. 654-661, 1988.

[113] Pass, R. F., P. D. Griffiths, and A. M. August. "Antibody response to cytomegalovirus after renal transplantation: comparison of patients with primary and recurrent infections", J. Infect. Dis, Vol. 147. Pp. 40-46, 1983.

[114] Lazzarotto T, Guerra B, Gabrielli L, Lanari M, Landini MP. "Update on the prevention, diagnosis and management of cytomegalovirus infection during pregnancy". Clin Microbiol Infect, Vol. 17. Pp. 1285-1293, 2011.

[115] Forbes BA. "Acquisition of Cytomegalovirus infection :an Update”, Rev Clin Microbial, Vol. 2. Pp. 204-16, 1998.

[116] Sopori M. "Effect of cigarette smoke on the immune system", Nat Revi Immun, Vol. 2. Pp. 372-377, 2002.

[117] Arson Y, Shoenfeld Y, Amital H. "Effects of tobacco smoke on immunity, inflammation, and autoimmunity", $J$ Autoimmun, Vol. 34. Pp. J258-65, 2010.

[118] Hsiao H-M, Sapinoro RE, Thatcher TH, Croasdell A, Levy EP, et al. "A Novel Anti-Inflammatory and ProResolving Role for Resolvin D1 in Acute Cigarette Smoke-Induced Lung Inflammation”, PLoS ONE, Vol/Issue: 8(3). Pp. e58258, 2013. doi:10.1371/journal.pone.0058258

[119] Venners SC, Wang X, Chen C, et al. "Paternal smoking and pregnancy loss: a prospective study using biomarkers of pregnancy”, Am J Epid, Vol. 159. Pp. 993-1001, 2004.

[120] Nielsen A, Hannibal CG, Lindekilde BE, Tolstrup J, Frederiksen K, Munk C, Bergholt T, Buss L, Ottesen B, Grønbaek M, Kjaer SK. "Maternal smoking predicts the risk of spontaneous abortion", Acta Obstet Gynecol Scand, Vol/Issue: 85(9). Pp. 1057-65, 2006.

[121] Gangopadhaya R, Karoshi M, Keith L. "Anaemia and pregnancy : a link to maternal chronic diseases", Int $J$ Gynae Obstet, Vol. 115. Pp. S11-S15, 2011.

[122] Andrews NC. "Anemia of inflammation: the cytokine-hepcidin link", J Clin Invest, Vol/Issue: 113(9). Pp. 12513,2004

[123] Nemeth E, Rivera S, Gabayan V, Keller C, Taudorf S, Pedersen BK, et al. "IL-6 mediates hypoferremia of inflammation by inducing the synthesis of the iron regulatory hormone hepcidin", J Clin Invest, Vol/Issue: 113(9). Pp. 1271-6, 2004.

[124] Haurani FI. "Hepcidin and the anemia of chronic disease", Ann Clin Lab Sci, Vol/Issue: 36(1). Pp. 3-6, 2006.

[125] Michaels, M. G., D. Alcendor, K. St. George, C. R. Rinaldo, G. D. Ehrlich, M. J. Becich, and G. S. Hayward. "Distinguishing baboon cytomegalovirus from human cytomegalovirus: importance for xenotransplantation", $J$. Infect. Dis, Vol. 176. Pp. 1476-1483, 1997. 